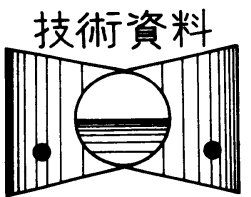

\title{
舶用パッケージ型空調装置 の冷却管の腐食対策*
}

\section{機関研究委員会 機関第三研究部会}

\author{
Countermeasure to Cooling Tube Corrosion \\ of Marine Packaged Air Conditioner
}

By Machinery Plant Committee Group 3

Recently, damage reports of packaged air conditioner due to corrosion of tubes have been remarkably increasing.

Judging from the condition of damaged coolers, the corrosion is caused by overvelocity of cooling water through tubes.

This paper gives some countermeasure to avoid overvelocity.

\section{1. まえがき}

本資料は，日本舶用機関学会機関研究委員会第三部会 の昭和 59 年度研究議題「制御室用パッケージ型エアコ ンの冷却器の防食対策」としてとりまとめられ，昭和 60 年 6 月をあって終了した.

パッケージ型エアコン(以降エアコンと略す)は，現在 まで船舶に多数装備されてきた。.そのような状況の中で, 特にての 2 3 年の間に, エアコンの冷却器用冷却管や 管板が腐食し，冷却水が漏洩するという事故が多発して いる. そこで, 本研究部会所属各社に対し, 漏洩事故の 数, 状態などについて実情調査を行い，その結果に基づ いて対策をとりまとめた.

\section{2. 漏洩事故の状況}

各社に対して行ったアンケートの結果，事故の状況は 大略次のようにまとめることができる.

1）漏洩事故の発生時期は, 大体本船就航後 3 か月〜 1 年以内である.

2) 漏㖂個所は, 冷却海水入口側の冷却管端部付近 （約 $40 \sim 150 \mathrm{~mm}$ ）及び管板に現われており，冷却管には 小孔があいている.

3）エアコンに接続されている冷却海水管の材質及び 内面処理は, SGP +ポリライニングと STPG 38 ( SCH 40)＋亜鉛メッキがあり，接続管材質や内面処理による 差異はあまり認められないようである.

4）冷却管材質については，漏洩のあったエアコンの 全てがアルミブラス管であり，防食板については，冷却 *原稿受付 昭和 60 年 12 月 30 日
器の各部材質が同種系統の金属で作られているため防食 板は不要ということで，装備されていない。

5）エアコン用冷却海水は，海水サービスポンプなど のような複数の水系統に供給できるポンプから供給され ている場合が多く，使用状況によっては，エアコンに多 量の冷却海水が流れる場合がある.

6）エアコンが喫水よりも十分高い位置に設置されて いる場合，または，ての冷却海水吐出管と居住区空調装 置の泠却海水吐出管と共用している場合, 冷却海水の落 下によるエゼクタ現象のため, エアコンへ計画水量以上 の過流量が流机ている場合がある.

\section{3. 漏洩事故の原因}

過去, 多数のエアコンが船舶に装備されたが, 漏洩事 故の報告例はあまり聞かなかった．とてろが最近かなり の数の事故が報告されている. てれらの一因としては, エアコンの冷却器の構造材質などの変更も考えられるが, それ以外の原因としては，下記のようなととが考えられ る.

1）流速過大による潰食 (インレットアタック)

2）流速過大による損傷(キャビテーション)

3）夾雑物（砂，小石など)による潰食

4) 付着物 (貝, 海藻など) による腐食

5）污染海水による腐食

6）複合要因による腐食，損傷

冷却管の漏洩箇所の発生位置及びその状態からみて, 流速過大や流体中の不純物などが複合的に作用して，発 生したあのと考えられるが，その中であ主原因としては， 1)の流速過大による潰食 (インレットアタック)や，2) 
の流速過大による損傷(キャビテーション)が考えられる.

\section{4. 対策}

対策としては, 冷却器本体の対策と配管系統の改善に よる対策を示すとととする.

4.1 冷却器本体の対策 メーカの対応について は，各社それぞれ異なっている，例えば，A社は冷却水 の流量が多少増えても過流速にならないように，余裕を 持たせた冷却器にモデルチェンジしようとしている（既 に変更されているものあある)。 また，B社は流量を制 限するために，定流量制御弁やオリフィスの設置をリコ メンドしている.

てのように対策はまちまちであるが，漏㖂を防止する ために過流速を避ける点では一致している。

具体的な対策としては，次のようなあのがある(メー カによって採用されている対策は異なる).

1) 冷却器の流速低減（パス数を 6 パスから 4 パスに 変更).

2）給水蓋を深くする（犠牲陽極を付けた時の乱流防 止).

3）冷却水出口側にオリフィスを設ける.

4）冷却管の材質変更（アルミブラスからキュープロ ニッケルに変更).

5）犠牲陽極の取付け.

4.2 造船所側の対策 造船所で採用できる対策 として考えられるのは, 冷却水の適正流量の確保である. 適正流量を確保するために，下記のような方法が考えら れる.

1）定流量調整弁の設置.

2）オリフィスによる流量制限.

3）出口弁開度による流量調整.

4）適正な流量配分計画.

5）高位置からの冷却海水吐出管之の共用を避ける.

てれらの方法について，次に説明する.

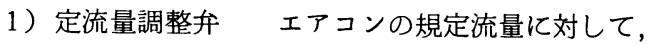
あらかじめ差圧を定めておく，流量が変化すれば，入口 側の圧力とばねの力の差により, 水路が自動的に調整さ れて規定流量になるように作動する。乙の弁の性能は， 初期調整の精度に左右されるので, 使用条件を正確に指 示しておかないと，付けてああまり効果がない場合ああ るので十分注意が必要である.

2）オリフィスによる流量制限（下記選定例は三菱重 工業(株)製 “ DP-K” 型の場合を示す） 過大流量時, オリフィスを通過する際の圧力損失を増大させ水量を制 限するととを目的とする.

オリフィスを装備するのは，下記の場合を一応の目安 とする.

a）ポンプ容量に余裕があり過ぎる場合.

b）船の契水深さの変化による流量変化が大きい時.

c） 1 台のポンプを複数の水系統に使用しているため

日本舶用機関学会誌 第 21 巻 第 6 号
使用台数の増減により, 冷却水量が変化するばあい.

ポンプ特性, 冷却水各系統ごとの水量, 圧力損失が判 明しない場合は, 目安として下記のオリフィスを組み込 むあのとする. これらのオリフィスを組み込むととによ り, 過大流量時, オリフィスでの通過抵抗が急増し, あ る程度過大流量を制限するととができる.

表 $1 \quad \mathrm{DP}-\mathrm{K}$ 型に組み込むオリフィス径の参考例 （ポンプ特性，水路抵抗，流量が不明な場合）

\begin{tabular}{|c|c|c|c|c|}
\hline 型式 例 & & A & & B \\
\hline $\mathrm{DP}-37 \mathrm{~K}$ & 内径 & $15 \mathrm{~mm}$ & 内径 & $12.5 \mathrm{~mm}$ \\
\hline $\mathrm{DP}-58 \mathrm{~K}$ & 内径 & $17.5 \mathrm{~mm}$ & 内径 & $15 \mathrm{~mm}$ \\
\hline $\mathrm{DP}-88 \mathrm{~K}$ & 内径 & $17.5 \mathrm{~mm}$ & 内径 & $15 \mathrm{~mm}$ \\
\hline $\mathrm{DP}-108 \mathrm{~K}$ & 内径 & $20 \mathrm{~mm}$ & 内径 & $17.5 \mathrm{~mm}$ \\
\hline
\end{tabular}

ポンプ特性や冷却水各系統でとの水量, 圧力損失が判 明している場合は次の順序でオリフィス径を決める。

a） “ $\mathrm{DP}-\mathrm{K}$ ” 江最大流量が流れる使用条件時の水量 を求める（他系統の通水量を減じた時, 船の契水が深い 時).

b）“ $\mathrm{DP}-\mathrm{K}$ ”に最小水量が流れる使用条件時の水量 を求める(他系統で最大水量使用時, 船の喫水が浅い時).

c） ポンプ特性より a)， b) の水路抵抗を求め，オリ フィス抵抗（図2）を上の世し，オリフィス組み込み後の 水量(図 1 の $Q_{3}$ )が “ $\mathrm{DP}-\mathrm{K}$ ” の使用可能上限水量にな るようにオリフィス径を決める.

d）選定したオリフィスを組み込み，b）の条件(水量 $\left.Q_{4}\right)$ で高圧カットしないととを確認する.

3）出口弁開度による流量調整訟法は造船所 の対策ではなく，ユーザ(乗組員)の協力によらなりれば

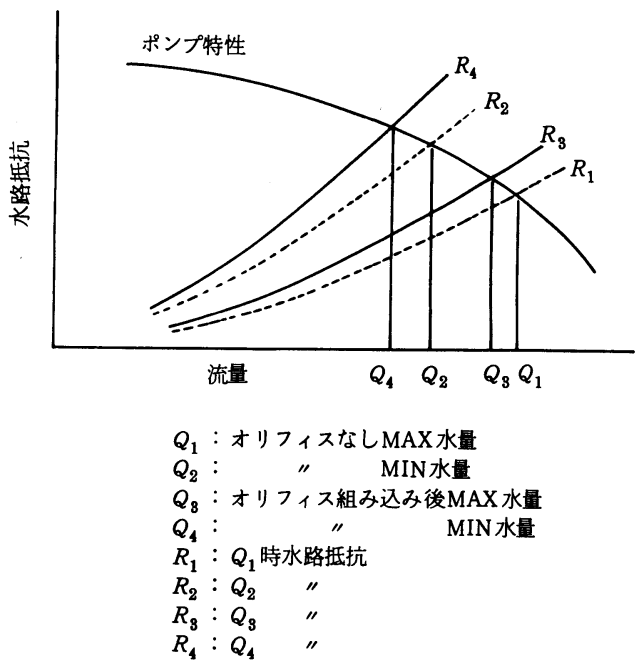

図 1 オリフィン組み込み前後の水量変化 （ポンプ特性，水路抵抗，流量が既知の場合） 


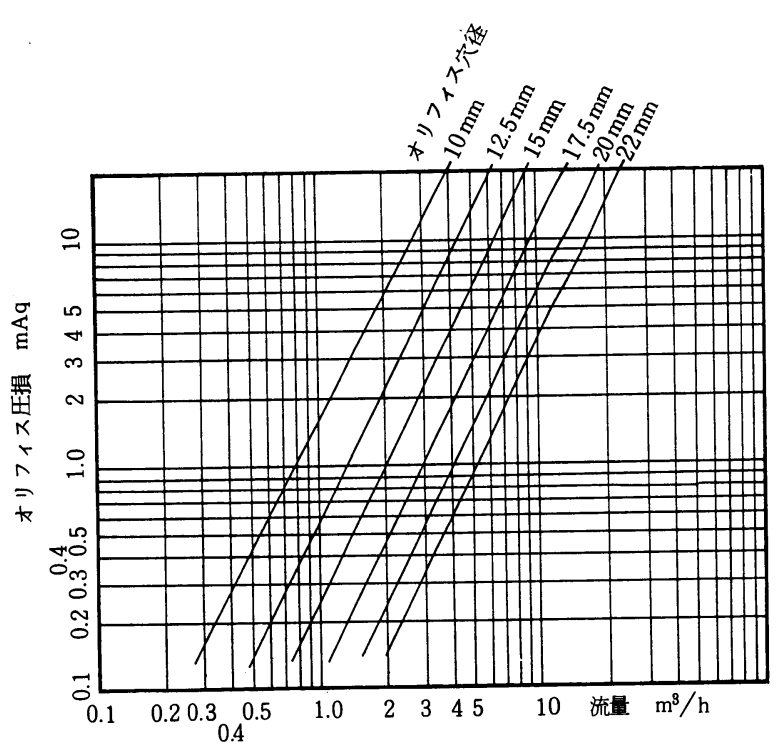

困 2 オリフィス圧損値

ならないあのであるが，流量調整の一手段と考えられる ので，ててに記述する.

季節, 航路によって冷却海水温度, 大気温度が変化す るから，それに応じて冷却海水量も流量の規定範囲内で 調整するととが必要である. したがって，ての方法は， 環境によって出口弁を調節しなりればならないという久 点がある.

適当な冷却水量は，まず冷却水入口温度，エアコン吸

表 $2 \quad \mathrm{PW}-2(\mathrm{~V}) \mathrm{AS}$ の適正高圧圧力

$\mathrm{kg} / \mathrm{cm}^{2} \mathrm{G}$

\begin{tabular}{|c|c|c|c|c|c|c|c|c|c|}
\hline \multirow{2}{*}{\multicolumn{2}{|c|}{$\begin{array}{l}\text { PW- } \\
2(\mathrm{~V}) \mathrm{AS}\end{array}$}} & \multicolumn{8}{|c|}{ 冷却水入口温度 } \\
\hline & & 18 & 20 & 22 & 24 & 26 & 28 & 30 & 32 \\
\hline \multirow{5}{*}{$\begin{array}{l}\text { 吸 } \\
\text { 这 } \\
\text { 湿 } \\
\text { 浗 } \\
\text { 度 }\end{array}$} & 18 & 10.2 & 10.9 & 11.7 & 12.4 & 13.2 & 13.9 & 14.7 & 15.4 \\
\hline & 20 & 10.5 & 11.2 & 12.0 & 12.7 & 13.4 & 14.1 & 14.9 & 15.6 \\
\hline & 22 & 10.8 & 11.5 & 12.2 & 12.9 & 13.6 & 14.4 & 15.1 & 15.8 \\
\hline & 24 & 11.0 & 11.8 & 12.5 & 13.2 & 13.9 & 14.6 & 15.3 & 16.0 \\
\hline & 26 & 11.3 & 12.0 & 12.7 & 13.4 & 14.1 & 14.8 & 15.5 & 16.3 \\
\hline${ }^{C} \mathrm{C}$ & 28 & 11.4 & 12.2 & 12.9 & 13.6 & 14.4 & 15.1 & 15.8 & 16.5 \\
\hline
\end{tabular}

表 $3 \mathrm{PW}-3(\mathrm{~V}) \mathrm{AS}$ の適正高圧圧力

$\mathrm{kg} / \mathrm{cm}^{2} \mathrm{G}$

\begin{tabular}{|c|c|c|c|c|c|c|c|c|c|}
\hline \multirow{2}{*}{\multicolumn{2}{|c|}{$\begin{array}{l}\mathrm{PW}- \\
3(\mathrm{~V}) \mathrm{AS}\end{array}$}} & \multicolumn{8}{|c|}{ 冷却水入口温度 } \\
\hline & & 18 & 20 & 22 & 24 & 26 & 28 & 30 & 0 \\
\hline \multirow{6}{*}{ 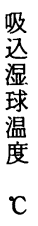 } & 18 & 11.9 & 12.7 & 13.4 & 14.1 & 14.9 & 15.6 & 16.3 & 17.1 \\
\hline & 20 & & .0 & 7 & 5 & 15.2 & 15.9 & 16.7 & \\
\hline & 22 & & 3 & & & & & & \\
\hline & 2 & 9 & 13.6 & 14.4 & & 9 & & 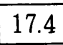 & 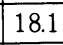 \\
\hline & 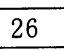 & 2 & 14.0 & 14. & 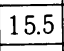 & 16.3 & 17.0 & 17.8 & 18 \\
\hline & 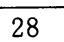 & 3.6 & 14.4 & 15.1 & 15.9 & 16.7 & 17.5 & \begin{tabular}{|l}
18.2 \\
\end{tabular} & 19. \\
\hline
\end{tabular}

込口での湿球温度及び高压压力のそれぞれの值を 読み，乙れらの值をメ一カの作成している水量調 整表と照らし合せ，それぞれの温度に対応する適 正高圧圧力になるように出口弁開度を調整するて とによって得られる.

参考例として三菱電機(株) 製のパッケージ型エ アコンの適正水量調整法を以下に示す.
a）冷却水入口温度測定
b）吸込み湿球温度測定エアコンの吸込口 で湿球温度 ${ }^{* 1}$ を测定する.

c）適正高圧圧力值読み取り 下表により， 冷却水入口温度ならびに吸込湿球温度から高圧圧 力値を読み取る．なお適正水量調整表は当該機種 のあのを利用するとと.

d）運転時の高圧圧力值の読み取り 圧縮機 の運転を確認し ${ }^{* 2}$, 前面の吸込みグリルを取りは ずして, 高圧圧力計の值を読み取る.

e）冷却水流量の調整適正高生圧力（表加 ら読み取った値) と運転高圧圧力(圧力計から読み 取った值) を比較し, 以下の操作により流量を增减して, 運転高圧圧力が適正高压圧力となるように調整する.

イ）運転高圧圧力が適正高圧圧力より高い場合は，冷 却水バルブを開ける.

ロ）運転高圧圧力が適正高圧圧力より低い場合は, 冷 却水バルブを絞る.

4）適正な流量配分計画一般にエアコンに供給す る海水ポンプは, 海水サービスポンプや補助冷却海水ポ

表 $4 \quad \mathrm{PW}-5(\mathrm{~V}) \mathrm{AS}$ の適正高圧圧力

\begin{tabular}{|c|c|c|c|c|c|c|c|c|c|}
\hline \multirow{2}{*}{\multicolumn{2}{|c|}{$\begin{array}{l}\mathrm{PW}- \\
5(\mathrm{~V}) \mathrm{AS}\end{array}$}} & \multicolumn{8}{|c|}{ 冷却水入口温度 ${ }^{C} \mathrm{C}$} \\
\hline & & 18 & 20 & 22 & 24 & 26 & 28 & 30 & 32 \\
\hline \multirow{5}{*}{$\begin{array}{l}\text { 吸 } \\
\text { 込 } \\
\text { 湿 } \\
\text { 浗 } \\
\text { 温 }\end{array}$} & 18 & 11.3 & 11.9 & 12.6 & 13.3 & 14.0 & 14.7 & 15.3 & 16.0 \\
\hline & 20 & 11.4 & 12.1 & 12.8 & 13.5 & 14.2 & 14.9 & 15.6 & \begin{tabular}{|l|l}
16.3 \\
\end{tabular} \\
\hline & 22 & 11.7 & 12.4 & 13.1 & 13.8 & 14.5 & 15.2 & 15.9 & 16.6 \\
\hline & 24 & 11.9 & 12.6 & 13.3 & 14.1 & 14.8 & 15.5 & 16.2 & \begin{tabular}{|l|l}
16.9 \\
\end{tabular} \\
\hline & 26 & 12.2 & 12.9 & 13.6 & 14.4 & 15.1 & 15.8 & 16.5 & \begin{tabular}{|l}
17.2 \\
\end{tabular} \\
\hline${ }^{C}$ & 28 & 12.5 & 13.2 & 14.0 & 14.7 & 15.4 & 16.2 & 16.9 & 17.7 \\
\hline
\end{tabular}

表 $5 \quad \mathrm{PW}-8(\mathrm{~V}) \mathrm{A} 3 \mathrm{~S}$ の適正高圧圧力

$\mathrm{kg} / \mathrm{cm}^{2} \mathrm{G}$

\begin{tabular}{|c|c|c|c|c|c|c|c|c|c|}
\hline \multirow{2}{*}{\multicolumn{2}{|c|}{$\begin{array}{l}\mathrm{PW}- \\
8(\mathrm{~V}) \mathrm{A} 3 \mathrm{~S}\end{array}$}} & \multicolumn{8}{|c|}{ 冷却水入口温度 C } \\
\hline & & 18 & 20 & 22 & 24 & 26 & 28 & 30 & 32 \\
\hline \multirow{5}{*}{$\begin{array}{l}\text { 吸 } \\
\text { 込 } \\
\text { 湿 } \\
\text { 浗 } \\
\text { 度 }\end{array}$} & 18 & 11.5 & 12.2 & 12.9 & 13.6 & 14.3 & 15.0 & 15.7 & 16.4 \\
\hline & 20 & 11.7 & 12.4 & 13.2 & 13.9 & 14.6 & 15.3 & 16.0 & 16.8 \\
\hline & 22 & 11.9 & 12.7 & 13.4 & 14.2 & 14.9 & 15.6 & 16.4 & 17.1 \\
\hline & 24 & 12.2 & 12.9 & 13.7 & 14.4 & 15.2 & 15.9 & 16.7 & 17.4 \\
\hline & 26 & 12.5 & 13.2 & 14.0 & 14.7 & 15.5 & 16.3 & 17.0 & 17.8 \\
\hline${ }^{\circ} \mathrm{C}$ & 28 & 12.8 & 13.5 & 14.3 & 15.0 & 15.8 & 16.6 & 17.3 & 18.1 \\
\hline
\end{tabular}

*1 湿球温度は温度計の感温部を水で湿らした布, ガーゼ等で包み測定すること.

${ }^{* 2}$ 圧縮機の運転は吹出口から冷風の出ているととで確認できる. 
ンプ等の多目的ポンプであり, 船の状態 (例えば, 荷役 中, 常用航海中など）によって必要海水量が変化する場 合が多い. この変化量は発電機関の運転台数分に相当し ているのが多く, かなりの変化量である.

ポンプを計画する場合，乙の変化量をできるだけ少な くなるようにするのが事故を防ぐ有効な手段となる．乙 れはポンプの初期計画で決まるので, 十分注意しておく べきである.

\section{5.あとがき}

パッケージェアコンには, 乗組員及び制御, 監視機器 類に対して良好な環境を維持するという目的が与えられ ている. 特に最近の高度化しつつある電子機器類は一定
環境下に置かれることが望ましく，ての意味からあパッ ケージェアコンの重要性が増加していると言えることが できる.

したがって，冷却管腐食によるパッケージェアコンの 事故を防止するために，早期かつ有効な対策が望まれる.

\section{文献}

1）三菱電機株式会社, 船舶用パッケージェアコン冷却水流量 調整要領書 (昭 57-10)

2）三菱重工業株式会社，舶用パッケージェアコン冷却水量の 件 (昭 58-2)

（担当者 佐世保重工業(株) 青山正臣) 